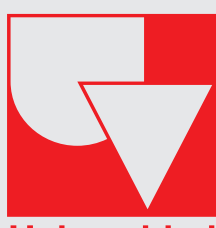

Universidad del Valle

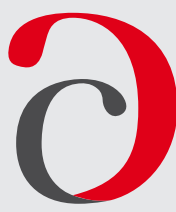

Cuadernos de Administración
Journal of Management

Print ISSN: 0120-4645 / E-ISSN: 2256-5078 / Short name: cuad.adm.

Pages: 158-171 / Vol: 36 / Issue: 67 / May - Aug. 2020

Faculty of Administration Sciences / Universidad del Valle /

Cali - Colombia

\title{
Gender job gaps and challenges in the digital economy: Findings from global governance entities
}

\author{
Brechas laborales de género y desafíos de la economía digital: \\ Hallazgos de las entidades de la gobernanza global
}

\author{
* María Victoria Delgado Cadenaid \\ Professor, Faculty of Administration Sciences, Universidad del Valle, Cali, Colombia \\ e-mail: maria.v.delgado@correounivalle.edu.co
}

Review Article

\begin{abstract}
This paper presents a detailed review of the most recent studies on gender-related work gaps that the leading entities of global governance have developed. Emphasis will be placed on the findings that point to persistent lower female participation in the field of work, lower wages, and little representation in senior corporate management positions and the public sector. The reviewed studies come mainly from entities leading the lawmaking actions of national governments, namely, the United Nations (UN), the International Labour Organization (ILO), the International Monetary Fund (IMF), the World Bank, and the Development Cooperation Organization. All agree that women face new and complex challenges, such as those brought on by the technological and scientific transformations that are changing the world's labor scenario, in addition to the already existing gaps. Issues such as digitization, automation, artificial intelligence, and other emerging technologies will further transform society. Such effects could profoundly impact women because, despite being trained in varied branches of knowledge, they are an underrepresented minority in the fastest growing areas, namely, the so-called STEM (the acronym for Science, Technology, Engineering, and Mathematics). Therefore, the above entities suggest actions that prevent the progress made from rapidly eroding and the emergence of modern forms of segregation, displacement, or precarization of women's work.
\end{abstract}

Keywords: Labor gaps, Gender, Technology, Global Governance, STEM.

\section{Resumen}

El artículo hace una revisión descriptiva de los estudios más recientes que sobre brechas laborales de género han elaborado las principales entidades de la gobernanza global, enfatizando los hallazgos que señalan la persistencia de menor participación laboral femenina, menores salarios y escasa representación en los cargos de alta dirección en las empresas y el sector público. Los estudios revisados son principalmente de entidades que orientan las acciones legislativas de los gobiernos nacionales, tales como la Organización de las Naciones Unidas, ONU; la Organización Internacional del Trabajo, OIT; El Fondo Monetario internacional, FMI; El Banco Mundial; la Organización de Cooperación

\footnotetext{
Social Communication and Journalism, Universidad del Valle, Colombia, Master's Degree in Logistics Management, Sydney
} University, Australia. 
para el Desarrollo, OCDE; los cuales coinciden en advertir que las mujeres además de encarar brechas tradicionales, enfrentan nuevos y complejos desafíos como los que traen las trasformaciones tecnológicas y científicas que están cambiando el escenario del trabajo en el mundo. Cuestiones como la digitalización, la automatización, la inteligencia artificial y otras tecnologías emergentes, transformarán aún más la sociedad. Lo efectos pueden ser de gran impacto para las mujeres pues pese a haberse educado en diversas ramas del saber, son minoría y están subrepresentadas en las áreas de mayor crecimiento, las Ilamadas CTIM, acrónimo para Ciencias, Tecnología, Ingeniería y Matemáticas. Por lo anterior, las entidades sugieren acciones que eviten la rápida erosión de los logros alcanzados y el surgimiento de inéditas formas de segregación, desplazamiento o precarización del trabajo femenino.

Palabras clave: Brechas laborales, Género, Tecnología, Gobernanza global, CTIM.

\section{Introduction}

Women's struggles for recognition, inclusion, and equality have varied throughout history. Suffrage was the first conquest after long and hard efforts at the dawn of the 20th century. The consolidation of old aspirations, such as rights to education, paid work, property, autonomy, protection of motherhood and childhood, has been achieved to varying degrees. However, aspirations for work and wage parity and access to leadership positions in organizations, society, and the State have followed a modest path of strengthening, filled with progress and setbacks, but without being firmly consolidated. Despite improvements gained, the gaps persist. Furthermore, the new and complex challenges emerging mainly from technological changes such as automation, artificial intelligence, and the so-called STEM (Science, Technology, Engineering, and Mathematics) areas are aggravating the situation. In these, women are underrepresented; that is, they represent a smaller share with lower pay and the repeated minority access to leadership positions.

Methodologically, this paper reviews the aforementioned global entities documents, starting from the United Nations Organization's as it is the leading body of the world's governance given the 193 nations that belonged to it as of 2019 . Documents from the International Monetary
Fund, the International Labor Organization (ILO), the World Bank, the Inter-American Development Bank, the Organization for Cooperation and Development (OECD) shall also be regarded. These bodies, which direct, even map, the political and economic actions of the world, have expressed their concern about the effects of digital transformation on women. They ask themselves: What are the gender implications of transforming the world of labor? How vulnerable are women, and what are the risks of displacement that technology brings to them? What policies are needed to ensure that technological changes contribute to gender parity in the labor market? (Brussevich, Dabla-Norris, Kamunge, Karnane, Khalid, and Kochhar, 2018).

As for the theoretical bases that support the studies we will review, they come from a wide variety of sources and vary in extension and approach. It is not possible to include them in detail due to their scope and number. Only some aspects of the evolution of the ongoing technological transformation, its expected maturity, and its impact on women's employment will be covered succinctly. That is why this paper will talk about a Reference Framework instead of a Theoretical Framework.

\section{Reference Framework}

The changes brought about by the opening of markets on account of globalization and the rise of trade in various regions of the world led millions of previously relegated women into the sphere of unpaid at-home work, factories, and manufacturing plants, which in turn resulted from foreign investment in various regions of the world. Their participation was carried out for them under disadvantaged conditions perpetuated in time and now result in higher unemployment rates, more precariousness, jobs at low hierarchical levels, and lower wages in the so-called vertical segregation (ILO, 2019a). Also, the vast majority of women worldwide continue to perform tasks essential to the life and maintenance of society, which are not recognized and generally go unpaid. When they are, wages are not in parity with other jobs, and the conditions under which they are fulfilled are often precarious, and of informality, lacking basic protections. This is 
the case of caregiving and household tasks, which are highly feminized and have little incorporation of technology and low pay. The said horizontal segregation confines women to unrecognized vital tasks, and keeps them from education or harnessing their capacities to assume social and political leadership roles and participate in the disruptive changes that the emergence of new technologies entails.

Furthermore, when women manage to overcome all the historical and cultural barriers of such segregation and even outperform men in their studies and training, the gender pay gap persists. As it is not always attributable to lesser education or their ability to perform a task, but to the mere fact of being a woman, eliminating the gender gap demands decisive actions. Many agencies and institutions have agreed on this outlook (ILO, 2019b). Gender gaps extend to the so-called 21st-century skills, i.e., the technological and scientific skills that are highly valued today and whose demand continues to grow rapidly.

In the most developed and prosperous OECD countries, women are better positioned than men in ICT skills. However, they are below in terms of STEM (Science, Technology, Engineering, and Mathematics) and management and communication skills (OECD, 2018). In Latin America and the Caribbean, the evidence available indicates that men outperform women in STEM skills (Agüero, Bustelo, and Viollaz, 2020).

As studies in the area of work and gender multiplied over the last two decades, valuable findings were made. For example, it became clear that women's increased economic and labor participation greatly improved social indicators in education, health, and, above all, poverty reduction. Other private studies conducted by consultants, universities and independent firms showed that the higher presence of women at different levels in firms, and especially in high positions, resulted in better economic performance and better managerial decisions (Devillard, SancierSultan, Zelicourt, and Kossoff, 2016).

In addition to the UN and many public and private agencies, the major international organizations decided to push for the closing of gender gaps in labor and seek more energetic women's empowerment, prioritizing these objectives in their agendas. The gender and work issues came to a preponderant place in the approach of these entities, devoting enormous resources, responsible structures to the subject, and more significant research and dissemination work.

In order to promote women's participation in all its member states and avoid delaying the closing of the vast disparities between men and women, the United Nations organized four major world conferences on women in the twentieth century. In the last one, held in Beijing (1995), the UN set a global platform for gender equality action and reaffirmed its commitment to developing women's potential within society, seeking to commit signatory countries to make adjustments to their domestic legislation to achieve such purposes. By accepting such pathways and agreements, almost without exception, the countries of the world began to transform their legal frameworks and making progress towards commitments acquired. In light of these programs, regional and national institutions aimed at the development and promotion of gender equality were created (Avolio and Di Laura, 2017).

Despite these efforts, agreements, and legislative changes, the gaps remain. The narrowing, and the bridging of the education gap in some regions, has given women prominence. However, they continue to be a minority in business leadership and senior public administration positions in almost all countries (World Economic Forum, WEF, 2020). Closing the labor and wage gap in the world is slow and uneven. Studies and reports have shown recent setbacks (Mc Kinsey \& Company Inc, 2018; ILO, 2018; ILO 2020). The technological field, a new source of disparities, adds on to the old debates.

The Beijing+20 report for Latin America and the Caribbean argues that gaps in women's access, use, and capacities need to be identified to maximize the benefits of ICT and address the root of these gaps. The authors point to women's low participation in science and technology careers among the causes of this gap. There is also less participation of women in the industry, especially at leadership and decision-making levels. Wage differences are detrimental to trained and 
professional women. The slow bridging of the gaps in the labor market attests to the need to shed light on existing obstacles (Sabanes, Roveri, Chamorro, Pineda, and Goñi, 2015).

For its part, the Economic Commission for Latin America (ECLAC), points out that ICTs enable women to become an active part of development, and support and outreach networks, and improve society by enabling access to new jobs and professions, participation in interactive learning initiatives and helping empower and improve their lives. They also enable women to occupy public space in society, creating resources, and contributing ideas and opinions, harnessing their ingenuity and creativity. (Plans to achieve gender equality in Latin America and the Caribbean (CEPAL, 2019).

Other researchers affirm that research on the digital gender gap is scarce, and there is no articulation among existing studies (Berrío, Marín, Ferreira, and Das Chagas, 2017). Female role models and mentors in science and technology in developed countries are lacking, and it is endemic and severe in Latin America (Schwartz, Casagrande, Leszczyski, and de Carvalho, 2006).

In the midst of this light-and-shadow approach regarding old aspirations, it is urgent to inquire about the new challenges of technological disruptions, which require a renewed outlook and refinement of strategies for closing gender gaps. The 2020-2029 decade is a moment of acceleration towards more significant technological and labor transformation. The social, economic, and political impacts are expected to be profound. The effects on jobs based on manual and repetitive tasks that entail low value-added are already surfacing. Analysis and control work, which requires qualifications and higher training, are also being affected.

The technological transition brought on by robotics, automation, artificial intelligence, machine learning, 3D printing, massive data processing, among others, will create disruptions or never-seen-before transformations in the workplace. Women are a weak flank in this transformation, although some believe that their lower presence in science and technology will affect them less, at first (Pampliega, 2019). For others, it is clear that not being in these highly growing sectors is already a disadvantage, and not being part of them in the near future could massively expel women from many labor markets and further confine them to the least relevant positions (García-Holgado, Camacho and García-Peñalvo, 2019). The so-called glass ceiling that prevents women from holding high positions could transform into one of steel.

Some studies suggest that the bridging of this gap in ICT and STEM should start from women's childhood education.

Regarding the most recent evolution dynamics of these varied information technologies, big data, artificial intelligence, and their impact on work, we are talking about three waves (Hawksworth, Berriman, and Goel, 2018). These are described below:

\subsection{Algorithmic Wave (Assisted Intelligence)}

Improvements involve automating simple tasks. This wave is underway and accounts for $3 \%$ of job losses in 2020. Since the overall female participation is lower on a global scale, and since unemployment is higher among young women and those over 50 years of age, it is possible to deduct that this wave will have, or has already had, incipient but adverse effects on female employment.

\subsection{Emerging Wave (or Increasing)}

Humans and machines collaborate in decision-making. It will cause the automation of repetitive and routine tasks, which are mostly performed by women. Its most significant impact shall be consolidated in some sectors as early as the 2020-2029 decade. It will mean the loss of a significant $30 \%$ of jobs as the wave progresses.

\subsection{Future Wave (Autonomous Intelligence)}

It enables the development of artificial intelligence capable of decision-making and solving problems in dynamic real-world 
situations. It will reach maturity between 2030 or 2040. It is not enough to predict whether there will be different gender impacts. However, if the change is rapid, women will be more likely to lose their jobs since they are already a minority in emerging technology sectors and less present in STEM education programs (Shook and Knickrehm, 2018). This wave will affect both men and women, perhaps differently. In any case, human labor will be highly replaced (Brown, Gosling, Bhushan, Sheppard, Stubbings, Sviokla, Williams, Zarubina, and Fisher, 2017).

\section{Theoretical review development: Studies by global bodies}

The research conducted a review of the studies produced by global governance institutions over the last five years concerning the gaps, progress, and genderrelated challenges facing women in the workplace around the world and its different regions. Recent documents, reports, and programs of agencies such as UN Women, UNESCO, the International Monetary Fund (IMF), the World Bank, the Inter-American Development Bank, the International Labor Organization, the Organization for Economic Cooperation and Development (OECD), and the Economic Commission for Latin America and the Caribbean (ECLAC). A review is made over six sections corresponding to the entities mentioned above

\subsection{UN Programmes, Reports, and Studies - UN Women}

In 2010, the UN General Assembly created UN Women, an agency specialized in promoting gender equality and women's empowerment. In 2000, the UN set the Millennium Development Goals agenda, which included guidelines for bridging gaps between men and women; hence, UN Women's idea emerged. The MDG Agenda was renewed in 2015, under the title of Sustainable Development Goals (SDGs). These included seventeen goals on various issues, including women's and girls' equality in all fields, especially healthcare, education, and the economic, political, and labor planes.
SDG 5 sets out the urgency of achieving gender equality and empowering women and girls, while SDG 8 promotes sustained, inclusive, and sustainable economic growth, full and productive employment, and decent jobs.

UN Women conducts global, regional, and national research and publishes an annual report. The ninth edition, issued in 2019, was entitled "Turning promises into action: Gender equality in the 2030 Agenda for Sustainable Development". It welcomes the unprecedented rise of the struggle for rights and proposes improvements on the generation of the statistics that will allow for rigorous monitoring over its progress. One proposed action was for those responsible for making gender equality a reality in each country to periodically render accounts (UNWomen, 2018).

Another report evaluating the SDGs and their achievements is: "Progress on the Sustainable Development Goals: The gender snapshot 2019." The 2019 edition's 24 pages render an account of the big difference in the overall female participation in labor at a rate of $55 \%$, while men's is $94 \%$. Concerning the gap in access to political power, it points out that a woman holds only 1 out of every four positions in world governments; a woman occupies only $27 \%$ of managerial positions regarding ministerial positions (Unwomen, 2019a,b).

On the other hand, the UN organized the WSIS or World Summit on the Information Society, where multiple stakeholders could discuss opportunities and the way to address challenges such as inequality or the digital divide. The Summit resulted in the creation of the Internet Governance Forum (IGF). The Forum has emphasized different significant aspects of women's access to the Internet such as online abuse and gender-based violence (2015), access barriers, the impact of complementary connectivity models in women's access to the Internet, and the opportunities and challenges women face to gain the skills needed to benefit from the future of work (Betancourth, Esterhuysen and Schout, 2013)

3.1.1. UN Women and the International Telecommunication Union (ITU) on 
closing the digital divide. In 2016, UN Women signed a partnership agreement with another agency, the International Telecommunication Union, specializing in telecommunications, and is responsible for regulating the sector internationally among the various administrations and service providing companies. The EQUALS agreement has created a digital gender inclusion map, an interactive visualization tool that compiles initiatives to reduce the digital gender gap worldwide (ITU, 2016).

According to ITU, between 2013 and 2019, the digital gender gap stayed in zero in North America and narrowed in European countries. However, in the Arab States, Asia, the Pacific, and Africa, the digital gender gap has grown since the number of new Internet users has been higher among men than in women since 2013 (ITU, 2019). The ITU's director, the first woman in that position in 154 years, Doreen Bogdan-Martin said: "Giving women and girls access to the Internet and the skills needed to use ICTs allows them to start new businesses, sell products to new markets, find jobs and access to education, financial and health services" (Bogdan-Martin, 2019).

The EQUALS program has also created a Research Group, made up of 29 academic partners to generate more yet better data on the digital inclusion of women and girls. The EQUALS in Tech award is an annual flagship event that promotes the actual involvement of women with ICTs and their rightful role in decision-making and production in this sector. "Girls' Day in ICT," an international commemoration of the United Nations aimed at bridging the gender digital gap, is celebrated in 171 countries on 25 April each year.

3.1.2. UNESCO and its contribution to closing gender gaps in the field of STEM. UNESCO is another branch of the UN focused on education, science, and culture. In 2014 , it published its priority action plan for "Gender Equality 2014 -2021," which provides a roadmap with crucial tasks, including educational inclusion and promotion of STEM fields (UNESCO, 2017). To promote the urgent greater integration of women in scientific areas, UNESCO is leading a contest that recognizes and stimulates female researchers' merits in several countries. It is doing so in partnership with the French firm L'Oreal.

Through another partnership, this time with the Global Mobile System (GSM), UNESCO created the Broadband Commission in 2010 to establish industry standards and regulations, and ensure that the gender gap in broadband access and use is closed. The preceding given that such a measure entails a significant impact on women's ability to connect to the world and access education and new forms of social and business participation. According to UNESCO Director-General Irina Bokova: "The continued development of new technologies and their application to economic, political and social processes, is creating new opportunities that can improve people's quality of life, but, to be sustainable, all new opportunities must be available to all, empower all, for the benefit of all, especially girls and women" (Bokova, 2019)

\subsection{The IMF Studies on Labor Gaps and Digital Inclusion}

With a large volume of data on the world's financial and economic status and its different sectors, the International Monetary Fund (IMF) can refine the analysis of the world of labor and its transformations. In recent years, the institution led by Christine Lagarde, and now by Kristalina Gueorguieva, has investigated gender job gaps and the impact of the transition to a digital economy within it.

A 2018 study, entitled: "Economic Gains From Gender Inclusion: New Mechanisms, New Evidence" assures that by having different skills, men and women manage to drive economic growth and profits beyond estimates by working together, which often surpasses the outcomes of a mere numerical increase in employees. "Gender diversity would increase GDP by up to 35\% in countries with delayed incorporation of women into work and impacting levels of consumption, leisure, and economic well-being" (Ostry, Álvarez, Espinoza, and Papageorgiou, 2018). Another IMF study that raises the disturbing change of direction in women's advancement is: "Is Technology Widening the Gender Gap? Automation and the Future of Female 
Employment." This publication indicates that, despite the improvements women have achieved, they face significant threats today as digitization, artificial intelligence, and machine learning affect jobs that consist of routine and repetitive tasks. Achievements attained with great effort may disappear if women continue to be overrepresented in automated work (Brussevich, 2018).

Alarmingly, the IMF notes the risks women face concerning the shift to a digital economy: in the emerging technology sector, women are $15 \%$ less likely than men to occupy managerial or professional positions, and an additional $19 \%$ to work as administrative or service staff (Kochhar, Jain-Chandra, and Newiak, 2017).

\footnotetext{
"The hard-won benefits from policies to increase the number of women in the paid workforce, and to raise their pay to equal that of men, could rapidly erode if women work predominantly in sectors and occupations that are at high risk of being automated" (Dabla-Norris and Kochhar, 2019, p. 9).
}

Other IMF analyses show that differences in the routine nature of tasks exacerbate gender inequality in pay for work. "Even considering factors such as differences in aptitude, experience, and choice of occupation, almost $5 \%$ of the wage gap between men and women, is due to women doing jobs that involve more routine tasks" (Frey and Osborne, 2013).

The opportunities that the IMF sees in the new STEM-dominated scenario, which both disfavors and threatens women, have a positive counterpart according to the entity. In rapidly aging, advanced and emerging economies, employment in traditionally female-dominated sectors such as healthcare and social services, jobs that require cognitive and interpersonal skills become more likely to grow and less prone to automation, but to address global aging population more workers will be needed, and they will require support from increased use of technologies to complement and boost productivity in healthcare work (Brussevich et al., 2018, p. 21).

From its studies and data analysis, the IMF has come to conclusions that lead it to recommend a set of actions for governments and entities responsible for closing gender gaps and women's empowerment (Legarde and Ostry, 2018).

\subsubsection{IMF Recommendations for Closing Gender Labor Gaps:}

- To invest as soon as possible in women's participation in science, technology, engineering, and mathematics (STEM).

- Encourage women to engage in science.

- Train and update women throughout their lives through companies, which should be supported by fiscal incentives.

- Close the gender gap in leadership positions.

- Countries may set relevant targets for organizations concerning recruitment and retention of employees and quotas for career advancement.

- To implement mentoring programs to put women on track to the top of businesses.

- Governments should promote and guarantee women's equal access to credit and connectivity, as well as physical infrastructure that allows access to education and other assets (Dabla-Norris and Kochhar, 2019).

- Social protection systems will need to adapt to new forms of work. To address the deterioration in income security associated with rapid technological changes, some countries might consider extending noncontributory pensions, and the adoption of guaranteed core income (Universal Income) could be justified.

\subsection{Studies by the International Labor Organization (ILO)}

The “Global Wage Report 2018/19: What lies behind gender pay gaps?" Is the latest and most recent worldwide study published by the International Labor Organization (ILO). The bleak information therein shows wages worldwide recorded their worst increase since 2008 and stood at levels equivalent to those of the years before the crisis. If China's high growth in jobs and wages were not included in the accounts, the figures 
would be negative. Paradoxically, there was economic recovery and low unemployment in high-income countries. The ILO finds no explanation for this behavior; it calls it an "enigma" (ILO, 2019b).

The gender pay gap measured in various ways, hourly or monthly, mean or average wage, still stands between $16 \%$ and $22 \%$. It follows that women in a downward wage scenario bear the brunt.

Although the ILO claims to analyze several methodological options to find the source of the gender gap, it has failed to do so. Therefore, the report states:

"Education and other labor market attributes explain relatively little of the gender pay gap at different points of the wage distribution. The unexplained part of the gender pay gap is generally dominates almost all countries, irrespective of income group" (ILO, 2018/2019, p.xvi).

In investigating the causes of the gap, the study finds that women tend to obtain a lower wage return from their education than men do, even if they have the same occupational status, which is simply an undervaluation of women's work. Highly feminized companies and sectors also have low wages. ILO suggests that Governments increase wages in these sectors and oppose undervaluation through legislative measures that prevent it. According to the ILO, only political actions and policymaking would close the pay gap.

ILO ensures that it requires more robust national statistics to carry out its diagnoses better. It points to the lack of reliable labor statistical systems in many countries. ILO calls for more proactive and decisive measures to promote the fastest closing of labor and wage gaps.

The ILO published "The Wage Gap between Men and Women in Latin America" in 2019. This publication reviews the Equal Pay International Coalition (EPIC) as an initiative launched in 2018 and led by the International Labor Organization (ILO), UN Women, and the Organization for Economic Cooperation and Development (OECD). This initiative brings together 173 countries to contribute to the Sustainable Development Goals' (SDGs) Target 8.5, which focuses on equal pay for women and men.

\subsubsection{ILO and its findings on gender,} science, and technology gaps. The International Labor Organization has the largest repository of statistical data on the world of labor. This data is available at ilostat. ilo.org. It publishes periodically reports that result from the analysis of that data. In its analysis about digital work and the gender gap, ILO concludes:

- Around the world, women are less likely to work in the technology sector, and when they do, they are generally underpaid. The average gender pay gap in technology stands at $21 \%$ (Based on data analysis from 75 countries). On the other hand, it is $16 \%$ for the economy in general.

- In 116 countries, regardless of income level or stage of development, women are underrepresented in the STEM sector, since the average participation of women is less than one third.

- According to the ILO's Global Wages Report, women in the technology sector are concentrated in lower-pay occupations, such as project management, rather than on higher-pay software development jobs (ILO, 2019b).

\subsection{Studies by the World Bank}

"Women, Business and the Law 2019: A Decade of Reform" is the fifth edition of an ongoing biannual study developed by the World Bank. The main findings of this last edition argue that "change is happening, but not fast enough. 2.7 billion women continue to have restricted access to the same jobs men do." No economy can reach its full potential without the full participation of women and men (Georgieva, Alonso, Dabla-Norris, and Kochhar, 2019).

In May 2018, the World Bank also released the results of another extensive research on the relationship between gender equality and countries' competitive capacity: "Truncated Potential: Unrealized Potential: The High Cost of Gender Inequality in Earnings." Therein was determined that "the world loses USD 160 billion in wealth due to gaps between the incomes that women and men earn throughout their lives (Georgieva et al., 2019). This represents an average of USD 
23,620 per person in 141 countries. Because women earn less than men, global wealth in human capital is about $20 \%$ lower than it could be" (Wodon and de la Brière, 2018)

Other findings of the study are:

- Achieving gender equality is not a shortterm process; it requires strong political will and concerted efforts on the part of Governments, civil society, and international organizations. Legal and regulatory reforms play a crucial role in that change.

- Considerable progress has been made over the past ten years. During this period, 131 economies introduced 274 reforms to laws and regulations to promote women's economic inclusion.

"The Little Data Book on Gender 2019" is an online publication that illustrates progress towards gender equality for 217 economies worldwide. The World Bank provides an updated data portal on the subject: https://datos.bancomundial.org/ tema/genero (World Bank, 2019).

The World Bank, through its regional subsidiary, The Inter-American Development Bank, has published the results of a pilot and proposed collection for measuring gender gaps in science, technology, and innovation in Latin America and the Caribbean. The first warning is that it is difficult to measure these gaps because there are few internationally available data and indicators. The results of the analysis confirm that there is a reduced female presence in strongly masculinized STEM disciplines and difficulties in reaching leadership positions in various spheres of National Science and Technology Systems, S\&T (López-Bassols, Grazzi, Guillard, and Salazar, 2018). In partnership with the Inter-American Dialogue, the IDB has also published the book "The Future of Work in Latin America, How Will Digitalization Impact and What to Do?" Therein is proposed that governments anticipate impacts, seize the window of opportunity, and close job gaps quickly (Bitar, 2020).

\subsubsection{The World Bank's findings on women and STEM, and its recommendations: Women's participation in university studies in STEM disciplines is}

still a minority. The situation is better at the doctoral level.

- Within STEM disciplines, women tend to specialize in natural sciences, agriculture and veterinary, and are under-represented in engineering and computer science. A significant number of women with degrees in science and technology do not pursue careers in these occupations.

- Female researchers tend to be concentrated in universities, government, and nonprofit organizations. Their presence in the business world must expand.

- Throughout their career, women are unable to attain senior positions, and this is true for academia, in companies, and public science areas and technology systems.

- Greater emphasis should be placed on the collection and analysis of human resources data in S\&T, including disaggregation by gender, training, and career paths, including doctorates and STEM sectors.

- Alternative sources of information such as universities, information from research support agencies, national S\&T councils, ministries, etc., should be used to produce periodic indicators, based on standard measures and classifications.

- The potential of digital tools (big data) to increase data sources and improve statistics needs to be harnessed.

- International and regional organizations and networks should be encouraged to expand the set of indicators they collect and publish. Dialogue among regional gender experts in science and technology should be facilitated.

- The development of experimental indicators should be encouraged in order to examine more complex issues such as tacit barriers that continue to hinder women's participation and advancement in scientific studies and careers, including work-family conflicts, strong male dominance in power structures of science and the persistence of stereotypes (Vaca-Trigo, 2019)

- In the publication "Women, Business and the Law," the Bank argues that no country can achieve its full potential without equal 
participation of women. Achieving it is good for all, especially for their progress and nations' (Ramalho and Trumbic, 2020).

\subsection{OECD's Gender Gap Studies}

The OECD report "Employment Outlook 2019, the Future of Work" published (with 36 countries partaking therein), states that "rapid action needed for people to meet challenges of the changing world of work." It also adds that "the transformation is profound, but we have the opportunity to seize this moment and build a future of work that benefits all." The OECD estimates that 14\% of existing jobs will disappear to automation over the next 15 years. Another $32 \%$ of tasks will change for the same reason (OECD, 2017). Many people are already lagging due to changes affecting different age groups, gender, and education. Many will not benefit from emerging jobs and will lose income or become precarious, says the 2018 report (OECD, 2018). Technological advances will impact the middle classes. In some countries, the population under precarious conditions is already over $40 \%$. The future of work will depend to no small extent on national public policies. With the right policies and the right institutions, digitization, globalization, and longevity can be harnessed to mitigate risks (OECD, 2019a), (OECD, 2019b).

A second report submitted in 2019, "Fast Forward to Gender Equality: Mainstreaming, Implementation, and Leadership," shows the strategies and tools used by governments in legislative matters to promote and innovate on gender equality issues. The report sets a baseline for monitoring progress based on recommendations made since 2015 by the gender equality council in public life. The report notes that the persistence of stereotypes and gender bias in public policymaking and budgetary decisions is preventing women from moving forward. Although women account for more than half of all public sector employees, there are still very few women in high-ranking public and decision-making positions.

As a way to drive change, the OECD has created the Social Institution and Gender Index Database (SIGI) and the portal "https://www.oecd.org/gender" as a resource to compare countries' status and statistics indicating inequalities in education, employment, entrepreneurship, health care, and development. The latest update of the OECD Gender Portal shows gaps such as the average $13.6 \%$ gender pay gap in the 36 OECD countries.

\subsection{The Global Economic Forum and the Global Gender Gap Report}

For the drafting of its annual report, "Global Gender Gap Report," the WEF build statistical databases with the profiles of 149 countries in order to visualize and compare the comprehensive picture of the global gender gap, which is measured in topics such as education, health care, economic and political inclusion (WEF, 2020). Some of the most relevant results in the report published in December 2019 are:

- At the current rate of progress in bridging the gender gap in politics, economics, health, and education, it will take 99.5 years to complete. The slowest progress is in the economic arena, where the gap jumped from $58.1 \%$ in 2018 to $57.8 \%$ in 2019 (WEF 2019).

- The 2018 report, carried out in partnership with LinkedIn, had already established eight groups of STEM professions. The figures confirm the low presence of women in six out of eight divisions. In cloud computing, only $12 \%$ of professionals are women. In engineering, they account for $15 \%$, and $22 \%$ in $\mathrm{AI}$, while only making up $7.4 \%$ in software and IT services. In networks and equipment, women account for $3.6 \%$, and in manufacturing, 5.4\%. The number of women does surpass men's in two fast-growing segments: "content production" and "peoples and cultures" (WEF, 2020). As these will be the areas with the highest job growth and highest pay, it foreshadows a gloomy picture for women should primary education and employment inclusion measures for them at STEM not be enacted (World Economic Forum, 2019).

\subsubsection{The Forum's report makes recommendations for reversing the situation:}

a. The most obvious one is to educate 
women or recycle women already on the market in the skills they need to fill the most demanded jobs. Failure to do so entails an economic cost because the shortage of skills in these professions would slow down economic growth.

b. Prepared women should have the inclusion and representation they deserve. In data science, although $31 \%$ of the personnel with relevant skills are female, only $25 \%$ of posts are female-held. There is no gender gap in digital specialist skills, but only $41 \%$ of these jobs are female-held.

c. There is a need to enhance diversity in recruitment, and to create inclusive work cultures.

\section{Conclusions}

By reviewing and comparing the publications issued in recent years by the central global governance bodies on gender labor gaps, we can see a bittersweet picture of women's recent progress. Since the years following the 2008 economic crisis, there have been imbalances and even setbacks in the speed of women's rise to corporate leadership and corporate boards. Crises seem to show the fragility of women's achievements and rights.

By the end of the second decade of the 21st century, in 2019, healthcare and education coverage gender gaps have reduced almost enough to being closed. Their ultimate bridging is estimated in decades, while the bridging of economic and labor gaps are estimated in centuries (Mc Kinsey \& Company Inc., 2018). Education is the nearlybridged gap; however, although women in South America account for $60 \%$ of graduates in tertiary and university degrees, they represent only $30 \%$ of all STEM graduates (Science, Technology, Engineering, and Mathematics) (BID, 2018). When women are present in these sectors, they fall on the lower salary scale (Bustelo, Suaya, and Viollaz, 2019).

In the case of the US, women are no longer silent. They have denounced the harassment, hostility, symbolic and verbal violence they go through, thereby revealing a very unflattering corporate landscape in Hollywood and the entertainment industries, but in a wide range of sectors. In 2018, the setbacks in the improvements hitherto achieved were revealed. The ILO considered that gender labor gaps could take about a century and a half to bridge, and such scope was extended to more than two centuries in 2018. Several wide-ranging studies agree thereon (Mc Kinsey \& Company Inc., 2018; ILO 2019b; WEF, 2020).

Studies and statistics warn of the risks foreshadowed for the 2020-2029 decade as a result of technological transformations in the world of work. Initially, manual and repetitive low-value tasks will be affected. Then, the analysis and control tasks that today require training and higher qualifications will also be eliminated. Given the rapid transformation of the workplace and the marked loss of millions of jobs, educational changes must be introduced to include women in these sectors, the STEM, where their presence is a minority today.

States, corporations, businesses, and all groups of women and gender researchers must act immediately, join wills and efforts, and help women strengthen their hard-earned achievements of decades and centuries. The future is not ineluctable, and it can be foreseen and planned for; by our actions today, we can create a future that will ensure the world's women full inclusion with justice and equality.

\section{Conflict of interest}

The author declares no conflict of interest.

\section{Source of Financing}

This work has not been financed by any entity whatsoever.

\section{References}

Agüero, A., Bustelo, M., y Viollaz, M. (2020). ¿Desigualdades en el mundo digital? Brechas de género en el uso de las TIC (p. 4). Recuperado de https://publications.iadb.org/es/desigualdadesen-el-mundo-digital-brechas-de-genero-en-eluso-de-las-tic 
Avolio, B. E., y Di Laura, G. F. ( 2017). Progreso y evolución de la inserción de la mujer en actividades productivas y empresariales en América del Sur. Revista de la CEPAL N 122.

Berrío, C., Marín, P., Ferreira, E., y das Chagas, E. (2017). Desafíos de la inclusión digital: antecedentes, problemáticas y medición de la brecha digital de género. Psicología, Conocimiento y Sociedad, 7(2). https://doi. org/10.26864/PCS.v7.n2.8

Betancourth, V., Esterhuysen, A., \& Schout, L. (2013). Global information society watch 2013 Women's rights, gender and ICTs. Retrieved from https://www.apc.org/sites/default/files/ gisw13 chapters 0.pdf

BID. (2018). El futuro del trabajo en América Latina y el Caribe (2018). Retrieved from https://publications.iadb.org/publications/ spanish/document/El_futuro_del trabajo_en Am\%C3\%A9rica_Latina_y el_Caribe_Una gran oportunidad_para_la_regi\%C3\%B3n versi\%C3\%B3n para imprimir.pdf

Bitar, S. (2020). El futuro del trabajo en América Latina. Cómo impactará la digitalización y qué hacer? Recuperado de https://www.thedialogue. org/analysis/el-futuro-del-trabajo-en-americalatina-como-impactara-la-digitalizacion-y-quehacer/?lang=es

Bogdan-Martin, D. (2019). Measuring digital development, Facts and Figures. Retrieved from https://itu.foleon.com/itu/ measuring-digital-development/gender-gap/

Bokova, I. (2019). The state of broadband 2019 Broadband as a Foundation for Sustainable Development. Broadband Commission for sustainable development. Retrieved from https://www.broadbandcommission.org/ Documents/Presentation_SoB19.pdf

Brown, J., Gosling, T., Bhushan, S., Sheppard, B. Stubbings, C., Sviokla, J., ... Williams, J., (2017). Workforce of the future: the competing forces shaping 2030. Retrieved from https://www.pwc. $\mathrm{com} / \mathrm{hu} / \mathrm{hu} / \mathrm{kiadvanyok} / \mathrm{assets} / \mathrm{pdf} /$ workforceof-the-future-the-competing-forces-shaping2030-pwc.pdf

Brussevich, M., Dabla-Norris, E., Kamunge, C., Karnane, P. Khalid, S., \& Kochhar, K. (2018). Gender, Technology, and the Future of Work. IFM. Washington. Retrieved from https://www. imf.org/ /media/Files/Publications/SDN/2018/ SDN1807.ashx

Brussevich, M. (2018). ¿Does trade liberalization narrow the gender wage gap? The role of sectoral mobility. European Economic
Review. 109, 305-333. https://doi.org/10.1016/j. euroecorev.2018.02.007

Bustelo, M., Suaya, A., y Viollaz, M. (2019). El Futuro del trabajo en América Latina y el Caribe: ¿Cómo será el mercado laboral para las mujeres? Recuperado de https://publications.iadb.org/es/ el-futuro-del-trabajo-en-america-latina-y-elcaribe-como-sera-el-mercado-laboral-para-lasmujeres

ComisiónEconómicaparaAméricaLatinayelCaribe (CEPAL). (2019). Planes de igualdad de género en América Latina y el Caribe: mapas de ruta para el desarrollo Estudios (№ 1, LC/PUB.2017/1-P/ Rev.1). Santiago, Chile: Observatorio de Igualdad de Género en América Latina y el Caribe. Recuperado de https://repositorio. cepal.org/bitstream/handle/11362/41014/

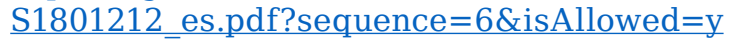

Dabla-Norris, E., y Kochhar, K. (2019). Cerrar la brecha de género, los beneficios de aumentar la participación de las mujeres en la fuerza laboral son mayores de lo que se pensaba. Finanzas $\&$ desarrollo. Recuperado de https://www.imf. org/external/pubs/ft/fandd/spa/2019/03/pdf/ closing-the-gender-gap-dabla.pdf

Devillard, S., Sancier-Sultan,S., Zelicourt,A., \& Kossoff, C. (2016) Women matter 2016. Reinventing the workplace to unlock the potential of gender diversity. Retrieved from https://www.mckinsey.com/fr/ /media/ McKinsey/Locations/Europe\%20and\%20 Middle\%20East/France/Our\%20Insights/ Women\%20matter\%202016/Women-Matter2016-Reinventing-the-workplace.ashx

Frey, C., \& Osborne, M. (2013). The future of employment: How susceptible are jobs to computerization? Oxford, United Kingdom: Oxford University. Retrieved from https://www. oxfordmartin.ox.ac.uk/downloads/academic/ The Future_of Employment.pdf

García-Holgado, A., Camacho, A., y GarcíaPeñalvo, F. J. (2019, octubre). La brecha de género en el sector STEM en América Latina: una propuesta europea. V Congreso Internacional sobre Aprendizaje, Innovación y Competitividad, Madrid, España. https://doi. org/10.26754/CINAIC.2019.0143

Georgieva, K., Alonso, C., Dabla-Norris, E., \& Kochhar, K. (2019). The economic cost of devaluing "womens work". Retrieved from https://blogs.imf.org/2019/10/15/ the-economic-cost-of-devaluing-womens-work/

Hawksworth, J., Berriman, R., \& Goel, S. (2018). Will robots really steal our jobs? An international 
analysis of the potential long term impact of automation. Retrieved from https://www.voced. edu.au/content/ngv\%3A78814

ILO. (2018). Perspectivas sociales y del empleo en el mundo. Tendencias del empleo femenino. Ginebra, Suiza: Oficina Internacional del trabajo. Recuperado de https://www.ilo.org/ wcmsp5/groups/public/---dgreports/---dcomm/--publ/documents/publication/wcms 619603. pdf

ILO. (2019a). Panorama temático laboral Mujeres en el mundo del trabajo Retos pendientes hacia una efectiva equidad en América Latina y el Caribe. Recuperado de: https://www.ilo.org/ wcmsp5/groups/public/---americas/---ro-lima/ documents/publication/wcms 715183.pdf

ILO. (2019b). Informe Mundial sobre salarios 20182019. Qué hay detrás de la brecha salarial de género? Recuperado de https://www.ilo.org/ global/research/global-reports/global-wagereport/WCMS 650653/lang--es/index.htm

ILO. (2020). Perspectivas sociales y del empleo en el mundo. Tendencias 2020. Recuperado de https://www.ilo.org/global/research/globalreports/weso/2020/lang--es/index.htm

ITU. (2016). Action plan to close the digital gender gap. Retrieved from https://www.itu.int/en/ action/gender-equality/Documents/ActionPlan. pdf

ITU. (2019). Measuring the digital development; Facts and figures. Retrieved from https://www. itu.int/en/ITU-D/Statistics/Documents/facts/ FactsFigures2019.pdf

Kochhar, K, Jain-Chandra, S., \& Newiak, M. (Eds.). (2017). Women, Work, and Economic Growth: Leveling the Playing Field. Washington DC., USA: International Monetary Fund. Retrieved from https://www.imf.org/en/Publications/Books/ Issues/2017/03/17/Women-Work-and-EconomicGrowth-Leveling-the-Playing-Field-43640

Legarde, C., y Ostry, J. (2018). Los beneficios macroeconómicos de la diversidad de género. Retrieved from https://voxeu.org/article/ macroeconomic-benefits-gender-diversity

López-Bassols, V., Grazzi, M., Guillard, C., \& Salazar, M. (2018). Las brechas de género en ciencia, tecnología e innovación en América Latina y el Caribe: resultados de una recolección piloto y propuesta metodológica para la medición. http://dx.doi.org/10.18235/0001082

Mc Kinsey \& Company Inc. (2018). Women in the Workplace 2018. New York, USA: McKinsey \& Company. Retrieved from https://www.mckinsey.com/featured-insights/ gender-equality/women-in-the-workplace-2018

OECD. (2017). The Pursuit of Gender Equality, an uphill battle Retrieved from https://dx.doi. org/10.1787/9789264281318-en

OECD. (2018). Bridging the digital Gender divide. Include, upskill, innovate. Retrieved from http:// hdl.voced.edu.au/10707/467799

OECD. (2019a). Fast Forward to Gender Equality: Mainstreaming, Implementation and Leadership. Retrieved from https://doi.org/10.1787/ g2g9faa5-en

OECD. (2019b). Perspectivas del empleo 2019. El futuro del trabajo (Serie: Informes OCDE $\mathrm{n}$. 85). Madrid, España: Ministerio de Trabajo, Migraciones y Seguridad Social. Recuperado de https://www.siis.net/es/documentacion/ catalogo/Record/542000

Ostry,J., Álvarez,J., Espinoza, R., \& Papageorgiou, C. (2018). "Economic Gains from Gender Inclusion: New Mechanisms, New Evidence". Retrieved from https://www.imf.org/en/Publications/ Staff-Discussion-Notes/Issues/2018/10/09/ Economic-Gains-From-Gender-Inclusion-NewMechanisms-New-Evidence-45543

Pampliega, G. (2019). Brecha de género y automatización. Efectos de la revolución digital en el mercado laboral español. Un mundo complejo. Recuperado de https:/l epampliega.com/blog/index.php/2019/07/17/ brecha-de-genero-y-automatizacion/

Ramalho, R., y Trumbic, T. (2020). Mujeres, empresa y el derecho: ¿de qué modo la ley incide en las oportunidades económicas de las mujeres?. Recuperado de https://blogs. worldbank.org/es/opendata/como-la-ley-incideen-las-oportunidades-economicas-de-lasmujeres

Sabanes, D., Roveri, F., Chamorro, L., Pineda, M., y Goñi, M. (2015). La mujer y las tecnologías de la información y comunicación (p. 25). Recuperado de https://www.genderit.org/sites/default/files/ informe beijing20 apc 0.pdf

Schwartz, J., Casagrande, L., Leszczynski, S., \& de Carvalho, M. (2006). Mulheres na informática: quais foram as pioneiras? Cadernos Pagu, (27). https://doi.org/10.1590/ S0104-83332006000200010

Shook, E., \& Knickrehm, M. (2018). "Reworking the revolution" Are you ready to compete as intelligent technology meets human ingenuity to create the future workforce? Retrieved from https://www.accenture.com/ acnmedia/pdf-69/ 
accenture-reworking-the-revolution-jan-2018pov.pdf

UNESCO. (2017). Sociedad digital: brechas y retos para la inclusión digital en América Latina y el Caribe. Recuperado de https://unesdoc.unesco. org/ark:/48223/pf0000262860_spa

Unwomen. (2018). Hacer las promesas realidad: La igualdad de género en la Agenda 2030 para el Desarrollo Sostenible. Recuperado de https://www.unwomen.org/es/digitallibrary/publications/2018/2/gender-equalityin-the-2030-agenda-for-sustainabledevelopment-2018

Unwomen. (2019a). Progress on the Sustainable Development Goals: The gender snapshot New York. Retrieved from https://www.unwomen. org/-/media/headquarters/attachments/ sections/library/publications/2019/progresson-the-sdgs-the-gender-snapshot-2019-singlepages-en.pdf?la $=$ en\&vs $=5813$

Unwomen. (2019b). La igualdad de género es un derecho y es un buen negocio. Recuperado de https://colombia.unwomen.org/es/biblioteca/ publicaciones/2018/01/boletin-laigualdaddegen eroesunbuennegocio

Vaca-Trigo, I. (2019). Oportunidades y desafíos para la autonomía de las mujeres en el futuro escenario del trabajo. Serie Asuntos de Género, (154). Recuperado de https://www.cepal.org/es/ publicaciones/44408-oportunidades-desafiosla-autonomia-mujeres-futuro-escenario-trabajo

Wodon, Q., \& de la Brière, B. (2018). The cost of gender inequality. Unrealized potential: The high cost of gender inequality in earnings. Retrieved from https://openknowledge.worldbank.org/ bitstream/handle/10986/29865/126579-Publicon-5-30-18-WorldBank-GenderInequalityBrief-v13.pdf? sequence $=1 \&$ isAllowed $=\mathrm{y}$

World Bank. (2019). The Little Data Book on Gender 2019. World Bank, Washington, DC.: USA. Retrieved from https://data.worldbank.org/ products/data-books/little-data-book-on-gender

World Economic Forum (WEF). (2018). The Global Gender Gap Report 2018. Geneva, Switzerland: WEF. Retrieved from http://www3.weforum. org/docs/WEF_GGGR_2018.pdf

World Economic Forum. (2019). Global Gender Gap Report 2020. Geneva, Switzerland: WEF. Retrieved from http://www3.weforum.org/ docs/WEF_GGGR_2020.pdf

World Economic Forum (WEF). (2020). The Global Gender Gap Report 2018. Geneva, Switzerland: WEF. Retrieved from http://www3.weforum. org/docs/WEF_GGGR_2020.pdf

\section{How to cite this paper?}

Delgado Cadena, M. V. (2020). Gender job gaps and challenges in the digital economy: Findings from global governance entities. Cuadernos de Administración, 36(67), 158-171. https://doi.org/10.25100/cdea.v36i67.8767 